\title{
BRIC-T ÜLKELERINNDE
}

\section{EKONOMİK BÜYÜME, DIŞA}

\section{AÇIKLIK, ELEKTRIKK TÜKETIMİ} VE ÇEVRE İLIŞKISSINE YÖNELİK

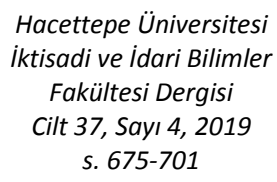

\section{AMPİRIK BİR ÇALIŞMA}

\author{
İbrahim ÖZMEN \\ Dr.Öğr. Üyesi, Selçuk Üniversitesi \\ Akşehir İktisadi ve İdari Bilimler Fakültesi \\ Maliye Bölümü \\ ibrahimozmen08@gmail.com
}

\section{Mustafa GERÇEKER \\ Dr.Öğr. Üyesi, Selçuk Üniversitesi \\ İktisadi ve İdari Bilimler Fakültesi \\ İktisat Bölümü \\ mustafagerceker@selcuk.edu.tr}

\section{Mehmet MUCUK}

Prof.Dr. Selçuk Üniversitesi

İktisadi ve İdari Bilimler Fakültesi

İktisatBölümü

mehmetmucuk@selcuk.edu.tr

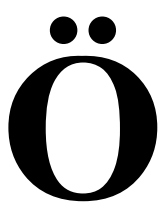

z: Tarım toplumundan sanayi toplumuna geçiş ile birlikte üretim miktarlar1, evrensel boyutta hız kazanan bir büyüme temposu yakalamıştır. Sanayileşmenin yanı sıra kentleşme ve nüfus artışı gibi faktörler de arz ve talep büyüklüklerinin değişiminde önemli rol oynamıştır. Üretimi artırmak için daha fazla doğal kaynak ve enerji kullanımı ise ekolojik dengeleri olumsuz yönde etkileyerek yaşam kalitesinin düşmesine neden olmuştur. Ancak belirli bir gelir düzeyine ulaştıktan sonra ülkeler, başlangıçta yarattıkları çevresel sorunları azaltmak için çözüm yolları arayışına girmektedirler. $\mathrm{Bu}$ çalışmada; ekonomik büyüme, ticari açıklık, elektrik tüketimi ve karbondioksit emisyonu $\left(\mathrm{CO}_{2}\right)$ arasındaki ilişki, 1992-2014 dönemine ait verilerden hareketle BRIC-T ülkeleri için panel veri analizi kullanarak test edilmektedir. Kónya (2006) panel nedensellik testi bulgularına göre; Rusya'da gelir ve $\mathrm{CO}_{2}$ arasında çift yönlü, Hindistan'da elektrik tüketiminden ve Brezilya'da ise dişa açıklıktan karbondioksit emisyonuna doğru olmak üzere tek yönlü bağıntılar bulunmaktadır. Diğer yandan MG tahminci yöntemi uzun dönem sonuçları Çin'de, kısa dönem sonuçları Türkiye'de ÇKE hipotezinin geçerli olduğunu gösterirken; $\mathrm{AMG}$ yöntemine göre Rusya, Çin ve Türkiye'de, CCE yöntemine göre de sadece Türkiye'de ÇKE hipotezi geçerlilik taşımaktadır.

Anahtar Sözcükler: Ekonomik büyüme, çevresel Kuznets Ĕgrisi, panel nedensellik, yatay kesit bă̆ımlılı̆̆ 



\section{ECONOMIC GROWTH, TRADE OPENNESS, ELECTRICITY Hacettepe University CONSUMPTION AND ENVIRONMENTAL and Administrative CONSUMPTION AND ENVIRONMENTAL Sciences RELATIONSHIP IN BRIC-T COUNTRIES: Vol. 37, Issue 4, 2019 pp. $675-701$ AN EMPIRICAL STUDY}

\author{
İbrahim ÖZMEN \\ Assist.Prof.Dr. Selçuk University \\ Akşehir Faculty of Economics and \\ Administrative Sciences \\ Department of Public Finance \\ ibrahimozmen08@gmail.com

\section{Mustafa GERÇEKER \\ Assist.Prof.Dr. Selçuk University \\ Faculty of Economics and Administrative \\ Sciences \\ Department of Economics \\ mustafagerceker@selcuk.edu.tr}

\section{Mehmet MUCUK}

Prof.Dr., Selçuk University

Faculty of Economics and Administrative

Sciences

Department of Economics

mehmetmucuk@selcuk.edu.tr bstract: With the transition from the
agricultural society to the industrial
society, the production quantities
have caught up a rapid growth
universally. In addition to industrialization, factors such as urbanization and population growth have also played an important role in changing supply and demand magnitudes. The use of more natural resources and energy to increase production has affected ecological balances negatively and has led to a decline in quality of life. However, after reaching a certain level of income, countries are seeking solutions to reduce the environmental problems. In this study, the relationships among to economic growth, trade openness, electricity consumption and carbon dioxide $\left(\mathrm{CO}_{2}\right)$ emission are tested using panel data analysis for BRIC-T countries over the period 1992-2014. According to Kónya (2006) panel causality findings, there appears to be a bidirectional linkage between income and $\mathrm{CO}_{2}$ in Russia. There is unidirectional causality from the electricity consumption to $\mathrm{CO}_{2}$ in India and from the openness to $\mathrm{CO}_{2}$ in Brazil. On the other hand, the MG estimator method showed that the EKC hypothesis is valid in China in the long run. This hypothesis is valid in Turkey in the short run. According to AMG estimator method EKC hypothesis is valid in Russia, China and, Turkey. Finally, CCE estimator method pointed out that EKC hypothesis is valid only in Turkey.

Keywords: Economic growth, environmental Kuznets Curve, panel causality, cross-sectional dependence. 


\section{GíRIŞ}

Bir ekonomik sistemin temel amaçları arasında toplumsal refah düzeyini maksimize etmek yer almaktadır. Toplumsal refah düzeyini maksimize edebilmek ise kalkınma sayesinde gerçekleştirilebilir. Çünkü bir ülkenin kalkınma süreci, büyümenin dışında yer alan özellikleri de içermektedir. Nitekim yüksek büyüme rakamlarına ulaşılmasına rağmen; yoksulluk sınırının altında yaşayan insanların sayısında bir artış eğilimi varsa veya işsizlik oranları sosyoekonomik dengeleri tehdit edebilecek seviyelere doğru ilerliyorsa refah düzeyinin yükseldiğini ifade etmek söz konusu değildir (Gönel, 2010: 10). Ancak yaşamın her bölümünü kapsayan geniş bir alanda olumlu değişimlerin sağlanması, oldukça uzun bir zaman dilimini gerektirir. $\mathrm{Bu}$ bağlamda Rostow (1966) kalkınmanın aşamalı bir şekilde gerçekleştiğini ve gelişim aşamalarının; geleneksel toplum, harekete geçme hazırlı̆̆ı, harekete geçiş, olgunluğa gidiş ve kitle tüketiminden meydana geldiğini ifade etmiştir.

Kuznets (1955) ABD ekonomisi için 1913-1948 dönemine ait verilere dayanarak yaptığı istatistiki bir çalışma ile kalkınmanın başlangıç aşamalarında artan gelir eşitsizliğinin, ileriki evrelerde kendiliğinden azalacağını ileri sürmüştür. Çünkü sanayileşmenin beraberinde getirdiği yeni zenginleşmeden ilk aşamada sadece küçük bir kesim yararlanırken; belli bir gelir düzeyinden sonra nüfusun giderek büyüyen önemli bir bölümü bu zenginlikten pay almaya başlamaktadır. Dolayısıyla gelir eşitsizliği çan eğrisine benzer bir görünüm arz etmekte, kalkınma sürecinde önce artarken sonra da giderek azalmaktadır (Piketty, 2013: 14-15).

\section{Grafik 1. Kuznets Ĕgrisi}

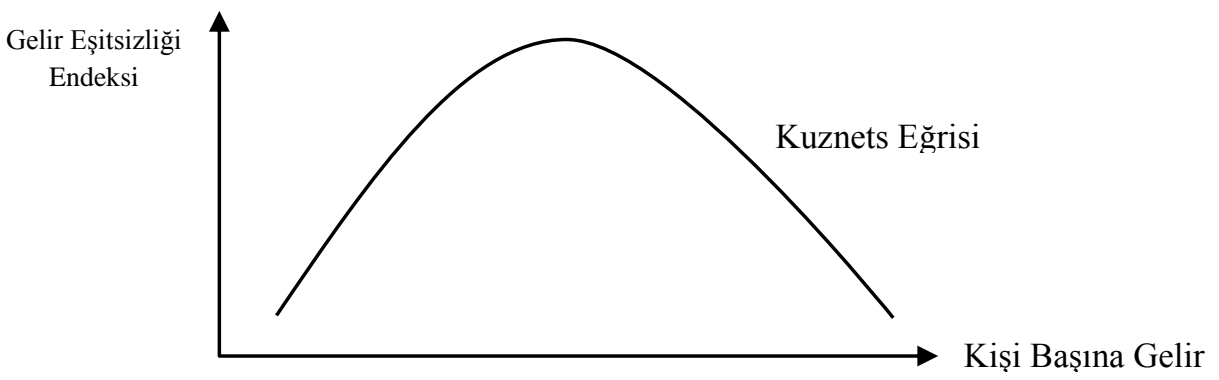

Kaynak: Nugent, 1983: 388.

Üretim miktarında meydana gelen artış her ne kadar gelir seviyesinin yükselmesine neden olsa da; daha fazla üretim yapabilmek için fosil yakıt kullanımının artırıması, çevre açısından önemli etkileri beraberinde getirmektedir. Nitekim Sanayi Devrimi ile birlikte kömürün temel enerji kaynağı haline gelmesi, dünya genelinde 
zehirli gaz emisyonlarının belirgin ölçüde artması ile sonuçlanmıştır. Zaman içerisinde kömürün yanı sıra petrol ve doğal gaz gibi geleneksel yakıtların da iktisadi faaliyetlerde yoğun bir şekilde kullanılmaya başlanması, ekolojik problemleri dünya gündeminin temel maddelerinden biri haline getirmiştir.

Ekonomik faaliyetler nedeniyle sürdürülemez bir konuma evrilen çevresel koşullar üzerine çeşitli çalışmalar ile dikkat çekilmiştir. Bunlardan Ehrlich (1968) "The Populatin Bomb", Meadows $v d$. (1972) ise "Limits to Growth" adlı kitapları ile nüfus artı̧ına eşlik eden ekonomik büyüme ortamının ekolojik dengesizlikler için elverişli bir iklim yarattığını ifade etmişlerdir. Birleşmiş Milletler (1987) tarafından yayımlanan "Our Common Future" isimli raporda da küresel ölçekte artış gösteren fosil yakıt kullanımının ve üretim düzeyinin çevre açısından yarattığı tehdide dikkat çekilmiş, sürdürülebilir kalkınma için temiz teknolojilerin önemine vurgu yapılmıştır.

Ekonomik büyüme ile çevre arasındaki ilişkiye yönelik tartışmaların hız kazandığı bir ortamda Grossman ve Krueger (1991), kuram ve uygulama bakımından dayanak noktası teşkil edebilecek bir çalışma gerçekleştirmişlerdir. ABD-Meksika Serbest Ticaret Anlaşması'na yönelik konferans için hazırlanan bu çalışmada, ticaret önündeki engellerin kaldırılmasına bağlı olarak ekonomik faaliyetlerin genişleyeceği belirtilmiştir. Ayrıca elde edilen bulgular; ekonomik faaliyetlerdeki genişlemenin düşük gelir seviyelerinde kirliliği artırırken; yüksek gelir seviyelerinde teknoloji faktörüne bağlı olarak kirliliği azaltacağını göstermiş̧tir.

Dünya Bankası Kalkınma Raporu için Shafik ve Bandyopadhyay (1992) tarafından hazırlanan çalışmada, Grossman ve Krueger'ın elde ettiği sonuçları destekler bulgulara ulaşılmıştır. Farklı gelişmişlik düzeyindeki 149 ülkeye ait ve 1960-1990 dönemini kapsayan verilere dayanılarak yapılan ekonometrik analizler; çevre kalitesini yansıtan tüm değişkenler üzerinde gelirin önemli bir etkiye sahip olduğunu göstermiş̧ir. $\mathrm{Bu}$ bağlamda başlangıçta gelir artarken bozulan çevre göstergelerinin, orta gelir düzeylerinden itibaren iyileşme eğilimi sergileyeceği ileri sürülmüştür. Böylece kişi başına düşen gelir ile çevre kirliliği arasında Kuznets Eğrisine benzer şekilde ters U biçiminde bir ilişki bulunduğunu ifade eden Çevresel Kuznets Eğrisi (ÇKE) hipotezi kuvvet kazanmıştır.

Holtz-Eakin ve Selden (1992), atmosferdeki sera gazları emisyonunun neden olduğu küresel ısınmaya yönelik tartışmalar üzerine, kişi başına düşen gelir ile $\mathrm{CO}_{2}$ emisyonu arasındaki ilişkiyi tahmin etmek ve küresel ölçekte emisyon değerlerinin gelebileceği seviyeleri öngörmek üzere bir çalışma yapmışlardır. Bu çalışmanın dört temel bulgusu şu şekildedir: 
- Ekonomi geliştikçe $\mathrm{CO}_{2}$ emisyonu azalarak artış eğilimi gösterecektir.

- $\mathrm{CO}_{2}$ emisyonu azalarak artış eğilimi gösterecek olmasına rağmen; dünya karbon emisyonu yıllık ortalama yüzde 1,8 oranında büyüme kaydedecektir.

- Çevre kirliliğinin daha fazla olduğu düşük gelirli ülkelerde ekonomi ve nüfus büyümesi daha hızlı gerçekleşecektir.

- Ekonomik kalkınma hızı, $\mathrm{CO}_{2}$ emisyonunun belirgin şekilde düşüş göstermesine neden olmayacaktır.

Panayotou (1993) ÇKE hipotezini ampirik olarak test etmek, bu hipotezin varlığına göre istihdam, teknoloji transferi ve kalkınma programları açısından etkin politikalar belirlemek amacıyla bir araştırma yapmıştır. Gelişmiş ve gelişmekte olan ülkelere ait yatay kesit verileri üzerinden yapılan analizler, söz konusu hipotezi destekler nitelikte sonuçlar ortaya koymuştur. Emisyon değerleri için dönüm noktasına karşlık gelen kişi başına gelir seviyesinin ise 3.800 dolar ile 5.500 dolar arasında olduğu hesaplanmıştır. Kişi başına gelir 1.000 doların altında iken çevresel bozulma oldukça yoğundur. Kişi başına gelir 1.000-3.000 dolar arasında iken ekonomi ve çevresel koşullarda kırsaldan tarıma, tarımdan endüstriye doğru olmak üzere belirgin yapısal dönüşüm gerçekleşmektedir. İkinci yapısal dönüşüm ise kişi başına düşen gelir 10.000 doları aşınca ortaya çıkmaya başlamaktadır. Bu dönüşüm neticesinde enerjiyoğun ağır sanayiden bilgi ve teknoloji yoğun temiz endüstrilere doğru bir hareketlilik yaşanmaktadır.

Selden ve Song (1994), ekonomik kalkınma ile kirlilik arasında ters- U şeklinde bir ilişki bulunduğunu ifade eden hipotezin doğruluğunu panel veri analizi ile test etmişlerdir. Elde edilen bulgular, hava kirliliğine neden olan dört temel unsurun (partiküller, sülfür dioksit, nitrojen oksit ve karbon monoksit) kişi başına GDP ile hipoteze uygun bir bağıntı içinde olduğunu yansıtmıştır. Ayrıca gelecek yıllarda küresel emisyon değerlerinin artacağı ifade edilirken; çok uzun dönemde bu değerlerin düşeceği tezi de desteklenmiştir.

Grossman ve Krueger (1995) çevresel koşulları yansıtan çeşitli göstergeler ile GSYIH arasındaki ilişkiyi panel veri analizi kullanarak sınamışlardır. Bu çalışmada bazı çevreci gruplar tarafindan ileri sürülen "ekonomik büyüme doğal ortama geri getirilemez boyutta zarar vermektedir" tezini destekleyen bir kanıta ulaşılamamıştır. Ancak çok fakir ülkelerde GSYİH artışının kritik gelir seviyelerine ulaşıncaya kadar çevresel koşulları bozduğu ifade edilmiştir. Bu çerçevede 1985 yılı fiyatları ile 8.000 doların altındaki kişi başına gelir düzeylerinde ekolojik sorunlar artarken; 10.000 
doların üzerindeki gelir düzeylerinde ise büyümenin çevreye zarar vereceğine dair hipotez reddedilmiştir.

ÇKE hipotezinin ortaya çıkmasına ve gelişim göstermesine katkıda bulunan yukarıdaki çalışmalara dayanarak, kişi başına düşen gelir ile çevre arasındaki teorik ilişki şu şekilde açıklanabilir (Carson, 2010; Dasgupta vd., 2002; Dinda, 2004; Grossman, Krueger, 1991; Stern, 2004a; Torras, Boyce, 1998; Lora vd., 2013): Kalkınmanın başlangıç aşamalarında insanlar, temiz hava ve sudan ziyade ağırlıklı olarak üretim ve gelir artışına öncelik vermekte, tarımdan sanayiye doğru geçiş süreci hiz kazanmaktadır.

Düşük verimlilik düzeylerinde üretim miktarındaki bu hızlı artış ise yüksek miktarda doğal kaynak ve fosil yakıt kullanımını beraberinde getirdiği için kirlilik düzeyi yükselmektedir. Ayrıca gelişmiş ülkeler, kirlilik yaratan endüstrilerin çevreye verdiği zararları minimize etmek üzere düşük gelirli ülkelere yatırımlarını kaydırmaktadırlar. Bu durum geri kalmış ülkelerde bir taraftan üretimin ve gelirin artmasına yardımcı olmakta; diğer taraftan ise çevresel bozulmayı beraberinde getirmektedir. Ancak belli bir gelir düzeyine ulaştıktan sonra, yüksek teknolojili üretim araçlarının daha fazla devreye girmesi, çevre standartlarının yükselmesi, temiz kaynaklara yönelik toplumsal talebin artması ve düzenleyici kurumların etkili politikalar üretip uygulaması gibi unsurlar kirliliğin azalmasına katkıda bulunmaktadır. Bu bağlamda Çevresel Kuznets Eğrisi, Grafik 2'de verilen bir görünüm arz etmektedir.

Grafik 2. Çevresel Kuznets Eğrisi

Çevresel Bozulma

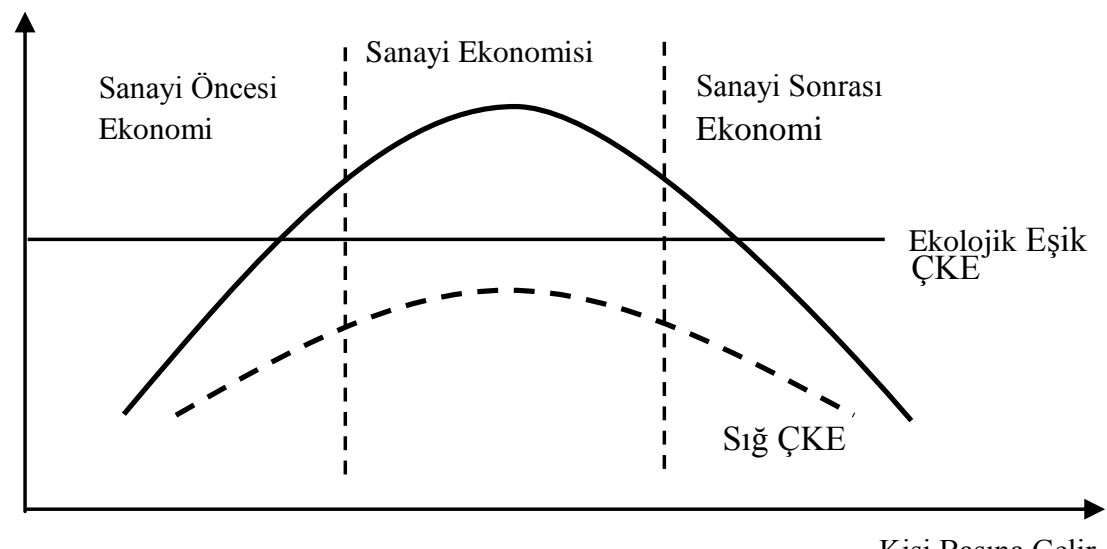

Kaynak: Panayotou, 1993: 16; Panayotou, 2003: 46 çalışmalarından hareketle tarafımızdan hazırlanmıştır. 
Ekolojik bakımdan her ülke için farklı bir eşik değeri söz konusudur. Bu değerin üzerinde gerçekleşen kirlilik, geri döndürülemez çevre sorunlarına neden olabileceği gibi; ülke için başka sorunları da beraberinde getirebilecektir. Dolayısıyla ülkelerin emisyon değerlerini eşik seviyelerde tutmaya çalışmasında fayda bulunmaktadır. Çevresel düzenlemeler ve uluslararası işbirlikleri, kalkınmanın başlangıç aşamalarında, telafisi zor çevre problemlerine yol açmadan büyümenin sağlanmasına imkan tanıyacaktır. "Sı̆̆" ya da "basık" olarak nitelendirilen Çevresel Kuznets Eğrisi; belirli standartlar, denetimler ve uygulamalar çerçevesinde yürütülen ekonomik faaliyetlere bağlı olarak kişi başına düşen gelir ile kirlilik arasındaki ters-U şeklindeki ilişkiyi göstermektedir (Panayotou, 1993; Sommerova, 2018).

Üretim tekniklerinde meydana gelen köklü değişimlere ilave olarak kentleşme ve nüfus artışı gibi faktörler hem toplam talebin hem de toplam arzın evrensel boyutta artmasına neden olmaktadır. Talebi karşılamak amacıyla daha fazla üretim faktörünün istihdam edilmesi ise ekolojik dengeleri olumsuz yönde etkileyebilmektedir. Nitekim ormanlık alanların azalması, zehirli gaz emisyonlarının artması, su kaynaklarının zarar görmesi, hava kirliliği ve toprăğı kalitesinde meydana gelen bozulmalar yaşam standartlarının düşmesine yol açmaktadır. Bu çalışmanın amacı; ekonomik büyüme, dışa açıklı ve elektrik tüketimi ile çevre kirliliği arasındaki ilişkiyi 1992-2014 dönemine ait yıllık verilerden hareketle BRIC-T ülkeleri (Brezilya, Rusya, Hindistan, Çin, Türkiye) için panel veri analizi kullanarak test etmektir. Diğer araştırmalardan farklı olarak çalışmada, yatay kesit bağımlılı̆ııı ve heterojenliği dikkate alan Kónya (2006) panel nedensellik analizi yapılmıştır. Ayrıca oluşturulan model ile kısa ve uzun dönem katsayıları tahmin edilmiştir. Dört bölümden oluşan bu çalışmanın birinci bölümünde literatür taraması, ikinci bölümünde ise analizlerde kullanılacak veri ve model hakkında bilgiler yer almaktadır. Üçüncü bölümde metodoloji hakkında bilgi verilmekte, dördüncü bölümde ise ekonometrik bulgular sunulmaktadır. Sonuç bölümünde de, ulaşılan bulgulardan hareketle çevre dostu büyüme politikalarına değinilmektedir.

\section{LITERATÜR TARAMASI}

Çevresel Kuznets Eğrisinin geçerliliğini test etmek üzere çok sayıda çalışma yapılmış olmakla birlikte; bu çalışmalarda birbirinden farklı sonuçlara ulaşılmıştır. Literatürde panel veri analizini kullanan çeşitli çalışmalara dair özet bilgiler aşağıda yer almaktadir.

Sülfür emisyonlarından kaynaklanan çevresel hasar ile ekonomik büyüme arasındaki ilişkiyi 73 OECD ve 31 OECD üyesi olmayan ülke için test eden Halkos (2003), analizlerinde rastgele katsayılar modeli ve Arellano-Bond Genelleştirilmiş Momentler Metodunu (A-B GMM) kullanmıştır. 1960-1990 dönemini kapsayan veriler 
yardımıyla gerçekleştirilen analizlerde A-B GMM, ÇKE hipotezinin geçerli olduğunu gösterirken; rastgele katsayılar modeli hipotezi doğrulamamıştır. Ayrıca ÇKE için dönüm noktası; 2.805 dolar ile 6.230 dolar aralığına karşılık gelmektedir.

Arı ve Zeren (2011), $\mathrm{CO}_{2}$ emisyonu ile kişi başına gelir arasındaki bağıntıyı sorgulayarak 17 adet Akdeniz ülkesi için ÇKE hipotezini 2000-2005 dönemine ait verilerden hareketle test etmişlerdir. Panel veri yönteminin kullanıldığı çalışmada, $\mathrm{CO}_{2}$ emisyonu ile kişi başına gelir arasındaki ilişkinin $\mathrm{N}$ şeklinde olduğu sonucuna ulaşılmıştır. Ayrıca ampirik bulgular, nüfus yoğunluğu ve enerji tüketiminin $\mathrm{CO}_{2}$ emisyonunu pozitif yönde etkilediğini göstermiştir.

Sambodo ve Lestari (2012), gelişmekte olan ülkeler için ÇKE’nin şeklini analiz etmişlerdir. Elde edilen bulgulardan ilkine göre; kişi başına GSYIH ile kişi başına karbon emisyonları arasında hipoteze uygun bir ilişki söz konusudur. İkinci olarak ekonomik yapıda tarımdan hizmetler sektörüne doğru bir geçiş, karbon emisyonlarının düşmesine pozitif yönde etki etmektedir. Üçüncü olarak ise kişi başına GSYİH'da meydana gelecek bir artış, kısa döneme göre uzun dönemde daha yüksek $\mathrm{CO}_{2}$ emisyonuna yol açmaktadır.

Erol vd. (2013), ABD Ticaret Departmanı'nın yükselen piyasa ekonomileri şeklinde sınıflandırdığı 10 ülke kapsamında gelir düzeyi ile çevre kirliliği arasındaki ilişkiyi incelemişlerdir. Panel veri tekniğinin kullanıldığı bulgular, analize konu olan ülkelerde ÇKE yaklaşımının geçerli olduğunu ortaya koymuştur.

Lapinskienè $v d$. (2013), sera gazları emisyonu ile GSYIH arasındaki ilişkiyi 1995-2008 dönemine ait verilerden hareketle Baltık Ülkeleri için araştırmışlardır. Bulgular, söz konusu değişkenler arasında ÇKE hipotezinde ifade edildiği gibi ters-U şeklinde bir bağıntının bulunduğunu doğrulamıştır. Ayrıca kömür üretimi, enerji üzerinden alınan örtük vergi oranları ve enerji yoğunluğunun sera gazları emisyonu üzerinde pozitif bir etkiye sahipken; Ar-Ge ile çevre vergilerindeki artışın emisyon değerlerini düşürdüğü sonucuna ulaşılmıştır.

Aytun (2014), ÇKE hipotezinin varlığını araştırmak üzere 5 gelir grubunda 83 ülke için 1981-2010 dönemine ilişkin veriler yardımıyla panel veri analizi gerçekleştirmiş̧tir. Elde edilen bulgular gelir artışı ile çevre kirliliğinin azalacă̆ını ileri süren hipotezin geçersiz olduğunu göstermiştir. $\mathrm{Bu}$ sonuçlardan hareketle çevre kirliliğini azaltmak için aktif politikaların izlenmesi gerektiği ifade edilmiştir.

Farhani $v d$. (2014) ÇKE hipotezi ile ilgili iki farklı modeli MENA ülkeleri için 1990-2010 dönemine ait verilerden hareketle panel veri metotlarını kullanarak analiz etmişlerdir. Birinci modelde çevresel koşullardaki bozulma ile gelir arasında ters-U 
şeklinde bir ilişki olduğunu ifade eden ÇKE hipotezi doğrulanmıştır. Modifiye edilmiş ÇKE olarak adlandırılan ikinci modelde ise sürdürülebilirlik ile insani kalkınma arasında yine ters-U şeklinde bir bağıntı olduğu gözlenmiştir. Ayrıca etkin çevresel politikaların oluşturulması bakımından ÇKE hipotezi, sürdürülebilirlik ve insani kalkınmanın son derece önemli olduğu sonucuna ulaşılmıştır.

Podkorytova ve Raskina (2014), ÇKE hipotezini Eski Sovyet Birliği'nin 15 ülkesi için 1990-2011 dönemine ait veriler yardımıyla panel veri yaklaşımını kullanarak test etmişlerdir. Ulaşılan sonuçlar; kişi başına GSYİH ile $\mathrm{CO}_{2}$ emisyonları arasındaki ilişkinin $\mathrm{N}$-şeklinde bir görünüme sahip olduğunu göstermiştir. Buna göre kişi başına GSYIH arttıkça kişi başına $\mathrm{CO}_{2}$ emisyonu önce artmakta, sonra azalmakta ve sonra tekrar artışa geçmektedir. Diğer taraftan enerji tüketimi ve kentleşme söz konusu ülkelerde emisyon değerlerinin artmasına neden olurken; doğrudan yabancı sermaye yatırımları ile $\mathrm{AB}$ üyeliği, kirlilik üzerinde istatistiki olarak anlamlı bir etki yaratmamaktadır.

Apergis ve Öztürk (2015), 14 Asya ülkesinden oluşan örneklem için 1990-2011 dönemine ilişkin verileri kullanarak ÇKE hipotezini test etmişlerdir. Panel veri tekniklerine dayalı eşbütünleşme analizi ve katsayı tahminlerinin yapıldığı çalışmadan elde edilen ampirik bulgular, söz konusu örneklem ve dönem aralığında ÇKE hipotezinin geçerli olduğuna işaret etmektedir.

Atasoy (2017), Amerika Birleşik Devletleri (ABD)'nin 50 eyaleti için 1960-2010 dönemine ilişkin verileri kullanarak ÇKE hipotezini test etmiştir. Panel veri tekniğine dayalı oluşturulan veri seti kullanılarak grup katsayı tahminleri yapılmıştır. Buna göre AMG (Augmented Mean Group) tahmin sonuçları 30 eyalet için ÇKE hipotezinin güçlü biçimde geçerli olduğuna işaret etmiştir. Buna karşıllk CCEMG (Common Correlated Effects Average Grup) tahmin sonuçları ise ÇKE hipotezinin geçerliliğine ilişkin istatistiki olarak daha zayıf kanıtlar sunmuştur.

Gashi ve Guma (2017), 8 Balkan Ülkesi için ÇKE hipotezini 1995-2012 dönemini kapsayan verilerden hareketle panel veri metodu kullanarak analiz etmişlerdir. Bağımlı değişkenin kişi başına GSYİH ve bağımsız değişkenlerin de kişi başına $\mathrm{CO}_{2}$ emisyonu ile nitrojen oksit emisyonundan oluştuğu modelde, her iki kirletici unsur ile gelir arasındaki bağıntının kuadratik bir yapıya sahip olduğu sonucuna ulaşılmışıtır. Buna göre gelirdeki artış birinci aşamada emisyon değerlerinin artmasına neden olurken; ikinci aşamada gelir artı̧̧ emisyon değerlerini düşürmektedir.

Hanif ve Santos (2017), ÇKE hipotezinin geçerliliğini gelişmekte olan 86 ülke için araştırmışlardır. Panel veriye dayalı katsayı tahminleri uygulanan bu çalışmada, 
1972-2011 dönem aralığına ilişkin veriler kullanılmıştır. Çalışmadan ulaşılan sonuçlar, ÇKE hipotezinin geçerli olduğunu ortaya koymuştur.

Topallı (2017), BRICS-T ülkelerinin 1960-2013 dönemine için ekonomik büyüme, ihracat ve $\mathrm{CO}_{2}$ emisyonu arasındaki koentegrasyon ilişkisini panel eşbütünleşme testleri kullanarak incelemiştir. Elde edilen bulgulara göre değişkenler arasında uzun dönemli bir bağıntı bulunamamıştır. Ayrıca G. Afrika ve Türkiye'de ihracat sektörlerinin ağırlıklı olarak kirlilik yaratan endüstrilere dayandığı görülmüsşür.

Zaman ve Moemen (2017), düşük, orta ve üst gelir grubunu temsil eden toplamda 90 adet ülkeden oluşan bir panel için ÇKE hipotezinin geçerliliğini sınamışlardır. 1975-2015 dönemi verilerinin kullanıldığ çalışmada, yöntem olarak da panel GMM tekniği tercih edilmiştir. Söz konusu panel için ele alınan dönemde ÇKE hipotezinin geçerli olduğu bulgusu elde edilmiştir.

Özkan ve Karakaş (2018), gelişmiş ve gelişmekte olan ülkelerin hedefledikleri daha fazla büyüme isteklerinin çevresel etkisini gelişmiş ve gelişmekte olan 25 Ekonomik Kalkınma ve İşbirliği Örgütü (OECD) ülkesi bazında incelemişlerdir. 19902014 dönemine ait veriler kullanılarak yapılan panel analizleri sonucunda ÇKE hipotezinin geçerli olduğu bulgusuna ulaşılmıştır.

\section{VERİ VE MODEL}

ÇKE hipotezinin test edilmesinde literatürde yaygın olarak kullanılan üç model şu şekildedir:

$$
\begin{aligned}
& Y_{i t}=G_{i t} \beta_{1}+G_{i t}^{2} \beta_{2}+G_{i t}^{3} \beta_{3}+\bar{G}_{i t} \beta_{4}+\bar{G}_{i t}^{2} \beta_{5}+\bar{G}_{i t}^{3} \beta_{6}+X_{i t} \beta_{7}+\varepsilon_{i t} \\
& X_{i t}=a_{0}+a_{Y} Y_{i t}+a_{Y Y} Y_{i t}^{2}+a_{Y Y Y} Y_{i t}^{3}{ }_{\cdots}+\varepsilon_{i t} \\
& \left.\ln E / P_{i t}=a_{i t}+y_{t}+\beta_{1} \ln (G S Y i S / P)_{i t}+\beta_{2} \ln (G S Y i S / P)^{2}\right\rfloor_{i t}+\varepsilon_{i t}
\end{aligned}
$$

Diğer yandan literatürde yer alan son dönem çalışmaları ise Ang (2008)'in çalışmasında yer verdiği ekonomik büyüme, karbondioksit emisyonu ve enerji tüketimi bağıntısından hareketle oluşturulan modellere dayanmaktadır (Shahbaz vd., 2012: 2949). Halıcıŏlu (2009), Nasir ve Rehman (2011), Shahbaz $v d$. (2012; 2014), Saboori $v d$. (2012), Kanjilal ve Ghosh (2013), Haq $v d$. (2016) ve Ertuğrul $v d$. (2016) ise modele dışa açıklık değişkenini de ekleyerek ticari serbestleşmenin çevre üzerindeki etkisini göz önünde bulundurmuşlardır. 
Karbondioksit emisyonu üzerinde etkili olan değişkenlerin belirlenmesi ve ÇKE hipotezinin test edilmesinde literatürde yer alan çalışmalardaki modeller esas alınarak, logaritmik model fonksiyonu şu şekilde oluşturulmuş̧ur:

$$
\mathrm{CO}_{2}=f\left(\mathrm{Y}, \mathrm{Y}^{2}, \mathrm{EC}, \mathrm{TO}\right)
$$

$\mathrm{Bu}$ fonksiyonel iliş̧iye hata teriminin de eklenmesi ile 4 numaralı denklem elde edilmektedir.

$$
\ln C O_{2 i t}=\beta_{0}+\beta_{1 i} \ln Y+\beta_{2 i} \ln Y^{2} \beta_{3 i} \ln E C+\beta_{4 i} \ln T O+\varepsilon_{i t}
$$

$\mathrm{Bu}$ çalışmada ekonomik büyüme, dışa açıklık ve elektrik tüketimi ile çevre kirliliği arasından ilişki, BRIC-T Ülkeleri (Brezilya, Rusya, Hindistan, Çin, Türkiye) için test edilmiştir. Söz konusu ülkelere ilişkin 1992-2014 dönemine ait veriler Dünya Bankası Dünya Kalkınma Göstergeleri (WDI) veri tabanından temin edilmiştir. Analizlerde değişkenlerin doğal logaritmaları kullanılmıştır.

Tablo 1. Değiş̧kenler ve Veri Kaynakları

\begin{tabular}{lccc}
\hline \hline Değişkenler & Sembol & Veri Kaynağı & Veri Dönemi \\
\hline \hline Kişi Başına GSYİH (2010 yılı fiyatları ile dolar) & $\ln Y^{*}$ & WDI & $1992-2014$ \\
Kişi Başına Elektrik Tüketimi (kWh) & $\operatorname{lnEC}$ & WDI & $1992-2014$ \\
Dışa Açıklı (Dış Ticaret/GSYİH) & $\operatorname{lnTO}$ & WDI & $1992-2014$ \\
Kişi Başına $\mathrm{CO}_{2}$ Emisyonu (metrik ton) & $\operatorname{lnCO}_{2}$ & WDI & $1992-2014$ \\
\hline \hline
\end{tabular}

* $\mathrm{Y}^{2}$ değişkeni kurulan modele uygun olarak tarafımızdan hesaplanmıştır.

\section{EKONOMETRİK YÖNTEM}

Ekonometrik analizlerde; yatay kesit bağımlılı̆̆ı ve homojenlik testleri ile Kónya (2006) panel nedensellik testi ve katsayı tahmincileri kullanılmıştır.

Yatay Kesit Bağımlılı̆ı ve Homojenlik Testleri: Küreselleşme ve finansal entegrasyon süreçleri bir ülkede meydana gelen herhangi bir ekonomik şokun veya konjonktürel dalgalanmanın diğer ülkeleri de etkilemesi açısından uygun bir ortam sunmaktadır (Shahbaz $v d$., 2017). Yatay kesit bağımlılık testi ile paneli oluşturan ülkeler arasında böyle bir etkileşimin olup olmadığı test edilmektedir. Bu test ayrıca değişkenler arasındaki ilişkiyi güvenilir bir biçimde tespit etmeyi sağlayacak yöntemlerin belirlenmesine de yardımcı olmaktadır. Yatay kesit bağımlılığını sınamak üzere yaygın olarak Breusch ve Pagan (1980: 242) tarafindan geliştirilen $\mathrm{CD}_{\mathrm{LM} 1}$, Pesaran (2004) tarafindan geliştirilen $\mathrm{CD}_{\mathrm{LM} 2}-\mathrm{CD}_{\mathrm{LM} 3}$ ve Pesaran $v d$. (2008) tarafından geliştirilen $\mathrm{LM}_{\mathrm{adj}}$ testleri kullanılmaktadır. Zaman boyutunun yatay kesit boyutundan büyük olması durumunda $(\mathrm{T}>\mathrm{N}) \mathrm{CD}_{\mathrm{LM} 1}$ testi uygulanırken (5 numaralı denklem); 
zaman ve yatay kesit boyutunun birbirine eşit olmas1 durumunda ise $\mathrm{CD}_{\mathrm{LM} 2}$ testi uygulanmaktadır. Diğer taraftan yatay kesit boyutu zaman boyutundan büyük ise $(\mathrm{T}<\mathrm{N})$ $\mathrm{CD}_{\mathrm{LM} 3}$ testinden faydalanılmaktadır (Kılıç $v d$., 2017). $\mathrm{CD}_{\mathrm{LM}}$ testleri grup ortalaması sıfır, ancak bireysel ortalamaların sıfirdan büyük veya küçük olması durumunda boş hipotezin kabul ya da reddine ilişkin sapmalı sonuçlar verebildiği için Pesaran $v d$. (2008: 108-110) LM istatistiğine varyans ve ortalamayı da ilave ederek bu sorunu çözmeye çalışmışlardır (Cebeci vd., 2018; Delice vd., 2012; Pata, Terzi, 2017, Nazlığlu $v d$., 2011). Yanlılığ düzeltilmiş $\mathrm{LM}$ istatistiği $\left(\mathrm{LM}_{\mathrm{adj}}\right)$ adını verdikleri yöntem (6 numaralı denklem), zaman boyutunda ve kesit boyutunda herhangi bir sınırlama bulunmayan panellerde kullanılabilmektedir (Özşahin, 2017). Söz konusu testlerden bu çalışmanın zaman ve örneklem büyüklüğüne uygun olan yatay kesit bağımlılık testlerine ait denklemler şu şekildedir:

$$
\begin{aligned}
C D_{l m 1} & =T \sum_{i=1}^{N-1} \sum_{j=i+1}^{N} p_{i j}^{2} \\
L M_{a d j} & =\sqrt{\left(\frac{2 T}{N(N-1)}\right)} \sum_{i=1}^{N-1} \sum_{j=i+1}^{N} p_{i j} \frac{(T-k) p_{i j}^{2}-\mu_{T i j}}{\sqrt{v_{T i j}^{2}}}
\end{aligned}
$$

Yatay kesit bağımlıı̆ı̆ını belirlemek üzere yapılan testlerde aşağıdaki hipotezler sinanır:

\section{$\mathrm{H}_{0}$ : Yatay kesit bağımlılığı yoktur}

\section{$\mathrm{H}_{1}$ : Yatay kesit bağımlılı̆̆ vardır}

Yukarıda belirtilen testler sonucunda hesaplanan olasılık değerleri 0.05 'den küçük olduğu takdirde "yatay kesit bağımlılığı yoktur" şeklindeki $\mathrm{H}_{0}$ hipotezi reddedilmekte ve paneli oluşturan ülkeler arasında yatay kesit bağımlılı̆ı̆ının olduğuna karar verilmektedir (Pesaran $v d$, 2008: 118-120). Modeldeki eğim katsayılarının yatay kesitler arasında farklı olup olmadığı ise Pesaran ve Yamagata (2008) tarafindan geliştirilen Delta veya homojenlik testleri ile tespit edilebilmektedir. Pesaran ve Yamagata (2008: 57), büyük örneklemler için $\tilde{\Delta}$ testini, küçük örneklemler için ise $\widetilde{\Delta}_{a d j}$ testini önermişlerdir. Söz konusu testlere ait denklemler şu şekildedir:

$$
\begin{aligned}
& \tilde{\Delta}=\sqrt{N}\left(\frac{N^{-1} \tilde{S}-k}{\sqrt{2 k}}\right) \\
& \tilde{\Delta}_{a d j}=\sqrt{N}\left(\frac{N^{-1} \tilde{S}-E\left(\tilde{z}_{i T}\right)}{\sqrt{\operatorname{Var}\left(\tilde{z}_{i T}\right)}}\right)
\end{aligned}
$$


Eğim katsayılarının homojenliğini belirlemek üzere yapılan delta testlerinde aşağıdaki hipotezler sınanır:

\section{$\mathrm{H}_{0}$ : Eğim katsayıları homojendir}

$\mathrm{H}_{1}$ : Eğim katsayıları homojen değildir

Yatay kesit bağımlılığını belirlemek üzere yapılan testlerde olduğu gibi homojenlik testlerinde de olasılık değerleri 0.05 'ten küçük olduğu takdirde $\mathrm{H}_{0}$ hipotezi reddedilmektedir. $\mathrm{Bu}$ testler sonucu elde edilen bulgular, nedensellik analizlerinde uygulanacak yöntemler hakkında önemli bilgiler sunmaktadır. Yatay kesit bağımlılığının ve heterojenliğin dikkate alınmadığı analizler ise sapmalı ve tutarsız neticeler verebilecektir (Topaloğlu, 2017).

Kónya (2006) Panel Nedensellik Testi: Panel veri analizlerinde yatay kesit bağımlılı̆̆ını ve heterojenliği birlikte dikkate alarak değişkenler arasındaki ilişkilerin yönünü belirlemek üzere Kónya (2006) tarafindan geliştirilen Bootstrap Panel Nedensellik testi kullanılmaktadır. Burada Wald testi ile Bootstrap Kritik Değerleri, değiş̧kenler arasındaki nedensel bağıntının yönü hakkında bilgi vermekte olup; Wald testi hangi kritik değerden yüksek ise ilgili anlamllık düzeyinde $\mathrm{H}_{0}$ hipotezi reddedilmektedir (Kar $v d ., 2011)$. Söz konusu testte kullanılan denklemler şu şekildedir:

$$
\begin{aligned}
& y_{1, t}=a_{1,1}+\sum_{i=1}^{m l y_{1}} \beta_{1,1, i} y_{1 i, t-i}+\sum_{i=1}^{m l x_{1}} \partial_{1,1, i} x_{k, 1, t-1}+\varepsilon_{1,1, t} \\
& y_{2, t}=a_{1,2}+\sum_{i=1}^{m l y_{1}} \beta_{1,2, i} y_{2, t-1}+\sum_{i=1}^{m x_{1}} \partial_{1,2, i} x_{k, 2, t-1}+\varepsilon_{1,2, t} \\
& = \\
& y_{N, t}=a_{1, N}+\sum_{i=1}^{m l y_{1}} \beta_{1, N, i} y_{N, t-1}+\sum_{i=1}^{m l x_{1}} \partial_{1, N, i} x_{k, N, t-1}+\varepsilon_{1, N, t}
\end{aligned}
$$


$\mathrm{Ve}$

$$
\begin{aligned}
& x_{1, t}=a_{2,1}+\sum_{i=1}^{m l y_{2}} \beta_{2,1, i} y_{1 i, t-i}+\sum_{i=1}^{m l x_{2}} \partial_{2,1, i} x_{k, 1, t-1}+\varepsilon_{2,1, t} \\
& x_{2, t}=a_{2,2}+\sum_{i=1}^{m l y_{21}} \beta_{2,2, i} y_{2, t-1}+\sum_{i=1}^{m l x_{2}} \partial_{2,2, i} x_{k, 2, t-1}+\varepsilon_{2,2, t} \\
& : \\
& x_{N, t}=a_{2, N}+\sum_{i=1}^{m l y_{2}} \beta_{2, N, i} y_{N, t-1}+\sum_{i=1}^{m l x_{2}} \partial_{2, N, i} x_{k, N, t-1}+\varepsilon_{2, N, t}
\end{aligned}
$$

9 ve 10 numaralı denklemlerde her bir ülkeye ait $j:(i)$ tüm $\partial_{1, j, i}$ sıfır değil iken; tüm $\beta_{2, j, i}$ sıfıra eşitse tek yönlü Granger nedensellik $(\mathrm{X} \rightarrow \mathrm{Y}), j:(i)$ tüm $\partial_{1, j, i}$ sıfır değil iken; tüm $\beta_{2, j, i}$ sıfıra eşitse tek yönlü Granger nedensellik (Y $\rightarrow$ $\mathrm{X}), j:(i)$ ne tüm $\partial_{1, j, i}$ sıfır değil ya da $\beta_{2, j, i}$ sıfır değilse çift yönlü Granger nedensellik (X↔ Y), $j:(i)$ tüm $\partial_{1, j, i}$ sıfır ve tüm $\beta_{2, j, i}$ sıfıra eşitse Granger nedensellik yoktur şeklindedir (Kónya, 2006: 981-982).

Katsayı Tahmincileri: Pesaran ve Smith (1995)'in geliştirdiği dinamik heterojen bir tahminci olan Ortalama Grup (MG) tahmincisi ARDL modeli için geliştirilmiştir (Bleackburne III, Frank, 2007:198). MG tahmincisine ait denklem şu şekildedir (Pesaran, Smith, 1995: 81-93):

$$
\begin{aligned}
& y_{i t}=a_{i}+\lambda y_{i, t-1}+\beta x_{i t}+v_{i t} \\
& v_{i t}=\varepsilon_{i}+\eta_{1 i,} y_{i, t-1}+\eta_{2 i} x_{i t},
\end{aligned}
$$

Ancak bu yöntem, parametrelerin heterojenliğini dikkate almakla birlikte; panelde yer alan yatay kesitler arasındaki bağımlılık ilişkisini göz önünde bulundurmamaktadır (Özşahin, Gömleksiz, 2016).

Diğer yandan Pesaran (2006) yatay kesit birimleri için uzun dönem katsayılarını belirlemek üzere yatay kesit bağımlılığını ve heterojenliği birlikte dikkate alan Ortak İlişkili Etkiler (CCE) tahmincisi ile MG tekniğinin bu eksikliğini gidermiştir. Yatay kesit bağımlılığı altında heterojen paneller için geliştirilen CCE tahmincisi; hem zaman boyutu yatay kesit boyutundan büyük olduğunda, hem de yatay kesit boyutu zaman boyutundan büyük olduğunda bile tutarlı ve asimptotik normal dağılım gösteren 
sonuçlar üretebilmektedir (Koçbulut, Altıntaş, 2016; Polat, Uslu, 2017). CCE tahmincileri bağımsız değişkenler ve gözlenemeyen ortak etkilerin durağan ve dişsal olduğunu varsaymakta ve bunların durağan (I(0)), birinci dereceden bütünleşik (I(1)) ve/veya eşbütünleşik olduğu durumlarda da tutarlıdır (Nazlığlu, 2010: 101). CCE tahmincisine ait denklem şu şekildedir:

$y_{i t}=a_{i}^{\prime} d_{t}+\beta_{i}^{\prime} x_{i t}+e_{i t}$,

Burada $d_{t}, n \times 1$ gözlenen ortak etkilerin vektörü, $x_{i t}$ ise $k \times 1$ vektörü ve bireysel değerleri göstermektedir.

$e_{i t}=\gamma_{i}^{\prime} f_{t}+\varepsilon_{i t}$,

14 numaralı denklemde $f_{t}$, dikkate alınmamış genel etkiyi, $\varepsilon_{i t}$ ise bireysel hata terimlerini temsil etmektedir (Pesaran, 2006: 971).

Modellerde yer alan değişkenlerin katsayılarını belirlemek amacıyla kullanılan tahmincilerden bir diğeri ise; Eberhardt ve Bond (2009), Eberhardt ve Teal (2010, 2011)'in geliştirdiği Genişletilmiş Ortalama Grup (AMG) tekniğidir. AMG tahmincisi yatay kesit bağımlılı̆ıını ve heterojenlik durumunu dikkate alarak bireysel katsayıların yanı sıra panele ilişkin katsayıları da vermektedir (Eberhardt, 2012: 62-65). Bu teknik aynı zamanda koentegrasyon katsayılarının aritmetik ortalamasını ağırlıklandırarak tahmin ettiği için diğer tahmincilere göre daha sağlıklı sonuçlar verebilmektedir (Songur, 2017). AMG testi serilerin I(1) olması (Altıntaş, Mercan, 2015: 368) durumunda veya serilerin bütünleşme derecelerinin farklı olması durumunda da uygulanabilmektedir (Eberhardt, 2012: 64; Acaravc1 vd., 2015: 125). AMG tahmin yöntemine ait denklem şu şekildedir:

$$
\begin{aligned}
& y_{i t}=\beta_{i}^{\prime} x_{i t}+\mu_{i t} \quad \mu_{i t}=a+\lambda_{i}^{\prime} f_{t}+\varepsilon_{i t} \\
& x_{m i t}=\pi_{m i}+\delta_{m i}^{\prime} g_{m t}+\rho_{1 m i} f_{1 m t}+\ldots+p_{n m i} f_{n m t}+v_{m i t} \\
& \text { Burada } m=1, \ldots, k \quad \text { ve } f_{\text {.mt }} \subset f_{t} \\
& f_{t}=e^{\prime} f_{t-1}+\varepsilon_{i t} \quad \text { ve } g_{t}=\kappa^{\prime} g_{t-1}+\varepsilon_{i t}
\end{aligned}
$$

Burada $x_{i t}$ gözlemlenebilir değişkenlerin vektörünü ifade etmektedir. Diğer yandan $f_{t}, \lambda_{i}$ ve $g_{t}$ lineer fonksiyonun ülkelere ait ağırlıklarını göstermektedir (Eberhardt, Bond, 2009: 2). 


\section{EKONOMETRİK BULGULAR}

Kişi başına düşen gelir ve karesi ile elektrik tüketimi, dışa açıklık ve karbondioksit emisyonu arasındaki ilişkilerin araştırıldığı bu çalışmada ilk olarak değişkenler arasındaki nedensellik ilişkisini tahmin etmek üzere yatay kesit bağımlılığı ve homojenlik testleri yapılmıştır. Elde edilen bulgular ise Tablo 7'de yer almaktadır.

Tablo 7'de yer alan yatay kesit bağımlılık testlerinden LM $_{\text {adj }}$ testine ait olasılık değerleri 0,05 'ten küçük olduğu için, yatay kesit bağımlılığının geçerli olduğu ve paneli oluşturan bir ülkedeki şokun diğer ülkelere de yayıldığı sonucuna ulaşılmaktadır. Ancak $\mathrm{CD}_{\mathrm{LM} 1}$ test sonuçları ise $\mathrm{LM}_{\text {adj }}$ test sonuçlarının tersini işaret etmektedir.

Diğer taraftan delta testlerine ilişkin olasılık değerlerinin de 0,05 'ten küçük olması, heterojenliğin geçerli olduğunu ve eğim katsayılarının yatay kesitler arasında farklılaştığını göstermektedir. LM $_{\text {adj }}$ sonuçları ise Kónya (2006) bootstrap panel nedensellik testinin ön koşullarını sağlanmaktadır.

Yatay kesit bağımlılığı ile heterojenliği birlikte dikkate alan nedensellik testleri kapsamında ilk olarak ekonomik büyüme ile karbondioksit emisyonu arasındaki ilişkiler analiz edilmiştir. Elde edilen bulgular Tablo 3'de yer almaktadır.

Tablo 3. Panel Nedensellik Sonuçları $\left(\mathrm{Y}, \mathrm{CO}_{2}\right)$

\begin{tabular}{|c|c|c|c|c|c|c|c|c|}
\hline \multirow{3}{*}{ Ülkeler } & \multicolumn{4}{|c|}{$\mathrm{H}_{0}: \ln \mathrm{Y}$ nedeni değildir $\operatorname{lnC\mathrm {O}_{2}}$ 'nin } & \multicolumn{4}{|c|}{$\mathrm{H}_{0}: \operatorname{lnCO} \mathrm{C}_{2}$ nedeni değildir $\ln \mathrm{Y}^{\prime}$ 'nin } \\
\hline & \multirow[b]{2}{*}{$\begin{array}{l}\text { Wald } \\
\text { Testi }\end{array}$} & \multicolumn{3}{|c|}{ Bootstrap Kritik Değerleri } & \multicolumn{4}{|c|}{ Bootstrap Kritik Değerleri } \\
\hline & & $\% 1$ & $\% 5$ & $\% 10$ & $\begin{array}{l}\text { Wald } \\
\text { Testi }\end{array}$ & $\% 1$ & $\% 5$ & $\% 10$ \\
\hline Brezilya & 13.863 & 33.028 & 25.440 & 22.616 & $14.661 * * *$ & 5.865 & 3.435 & 2.565 \\
\hline Rusya & $10.687 * *$ & 14.983 & 10.527 & 9.154 & $31.627 * * *$ & 3.171 & 1.537 & 1.093 \\
\hline Hindistan & 14.698 & 32.070 & 24.547 & 20.535 & 0.051 & 13.300 & 7.127 & 5.619 \\
\hline Çin & 0.428 & 15.193 & 11.649 & 10.324 & $7.619 *$ & 13.516 & 7.951 & 6.232 \\
\hline Türkiye & 4.248 & 77.448 & 54.885 & 53.512 & 0.602 & 63.482 & 49.886 & 40.928 \\
\hline
\end{tabular}

Not: Maksimum gecikme uzunluğu 3 olarak belirlenmiş ve Akaike bilgi kriteri tercih edilmiştir. Kritik değerler 1000 Bootstrap'a dayanmaktadır. *,** ve *** istatistiki olarak sırasıyla \%10, \%5 ve $\% 1$ anlamlılık düzeylerini göstermektedir.

Gelir ile karbondioksit emisyonu arasındaki nedensellik ilişkilerini gösteren bulgulara göre; sadece Rusya'da, gelir ve karbondioksit emisyonu arasında çift yönlü bir nedensellik bağıntısı söz konusudur. Diğer taraftan Brezilya'da \%1 anlamlılık düzeyinde, Çin'de ise \%10 anlamlılık düzeyinde karbondioksit emisyonundan gelire doğru tek yönlü bir nedensellik bulunmaktadır. 
Elektrik tüketimi ile karbondioksit emisyonu arasındaki nedensellik ilişkilerini gösteren bulgular Tablo 4'de yer almaktadır.

Tablo 4. Panel Nedensellik Sonuçları (EC, $\left.\mathrm{CO}_{2}\right)$

\begin{tabular}{lcccc|cccc}
\hline \hline \multirow{2}{*}{ Ülkeler } & \multirow{2}{*}{$\mathrm{H}_{0}$ : lnEC nedeni değildir lnCO ${ }_{2}^{\prime}$ 'nin } & \multicolumn{4}{|c}{$\mathrm{H}_{0}: \operatorname{lnCO}_{2}$ nedeni değildir lnEC'nin } \\
\cline { 2 - 9 } & Wald & \multicolumn{2}{c}{ Bootstrap Kritik Değerleri } & \multicolumn{4}{|c}{ Bootstrap Kritik Değerleri } \\
\cline { 2 - 10 } & Testi & $\% 1$ & $\% 5$ & $\% 10$ & Wald Testi & $\% 1$ & $\% 5$ & $\% 10$ \\
\hline \hline Brezilya & 13.705 & 36.133 & 28.116 & 24.527 & 0.174 & 20.602 & 12.158 & 8.620 \\
Rusya & 15.368 & 25.797 & 19.485 & 16.251 & $37.742 * * *$ & 11.633 & 8.176 & 6.377 \\
Hindistan & $41.374 * *$ & 43.191 & 34.699 & 30.075 & 0.004 & 22.412 & 13.876 & 11.096 \\
Çin & 4.686 & 38.443 & 32.364 & 28.324 & $11.317 * *$ & 12.120 & 8.996 & 7.002 \\
Türkiye & 7.319 & 75.911 & 47.911 & 39.386 & 0.092 & 59.927 & 42.312 & 34.481 \\
\hline \hline
\end{tabular}

Not: Maksimum gecikme uzunluğu 3 olarak belirlenmiş ve Akaike bilgi kriteri tercih edilmiştir. Kritik değerler 1000 Bootstrap'a dayanmaktadır. ** ve *** istatistiki olarak sırasıly $\% 5$ ve $\% 1$ anlamlılık düzeylerini göstermektedir.

Elektrik tüketimi ile karbondioksit emisyonu arasındaki nedensel ilişkileri gösteren bulgulara göre; Hindistan'da, elektrik tüketiminden karbondioksit emisyonuna doğru \%5 anlamlılık düzeyinde bir nedensellik bağıntısı söz konusudur. Diğer taraftan Rusya'da \%1 ve Çin'de ise \%5 anlamllık düzeyinde karbondioksit emisyonundan elektrik tüketimine doğru tek yönlü bir nedensel bağıntı bulunmaktadır.

Dışa açıklık ile karbondioksit emisyonu arasındaki nedensellik ilişkilerini gösteren bulgular Tablo 5'de yer almaktadır.

Tablo 5. Panel Nedensellik Sonuçları (TO, $\mathrm{CO}_{2}$ )

\begin{tabular}{|c|c|c|c|c|c|c|c|c|}
\hline \multirow{3}{*}{ Ülkeler } & \multicolumn{4}{|c|}{$\mathrm{H}_{0}$ : $\operatorname{lnTO}$ nedeni değildir $\operatorname{lnCO_{2}}$ 'nin } & \multicolumn{4}{|c|}{$\mathrm{H}_{0}: \operatorname{lnCO}_{2}$ nedeni değildir lnTO'nun } \\
\hline & \multirow[b]{2}{*}{ Wald Testi } & \multicolumn{3}{|c|}{ Bootstrap Kritik Değerleri } & \multicolumn{4}{|c|}{ Bootstrap Kritik Değerleri } \\
\hline & & $\% 1$ & $\% 5$ & $\% 10$ & Wald Testi & $\% 1$ & $\% 5$ & $\% 10$ \\
\hline Brezilya & $6.684 * * *$ & 6.472 & 4.194 & 3.015 & 2.957 & 12.984 & 9.349 & 7.664 \\
\hline Rusya & 0.041 & 9.097 & 5.869 & 4.565 & $43.387 * * *$ & 12.410 & 7.247 & 5.220 \\
\hline Hindistan & 8.964 & 14.410 & 10.917 & 9.656 & 1.401 & 25.436 & 17.184 & 13.374 \\
\hline Çin & 11.652 & 19.376 & 14.225 & 12.017 & 0.197 & 12.835 & 8.928 & 6.910 \\
\hline Türkiye & 3.328 & 8.113 & 5.351 & 3.784 & 3.660 & 14.498 & 7.446 & 6.031 \\
\hline
\end{tabular}

Not: Maksimum gecikme uzunluğu 3 olarak belirlenmiș ve Akaike bilgi kriteri tercih edilmiștir. Kritik değerler 1000 Bootstrap'a dayanmaktadır. *** istatistiki olarak \%1 anlamlılık düzeyini göstermektedir. 
Dışa açıklık ile karbondioksit emisyonu arasındaki nedensel ilişkileri gösteren bulgulara göre; Brezilya'da, dışa açıklıktan karbondioksit emisyonuna doğru \%1 anlamlılık düzeyinde tek yönlü bir nedensellik bağıntısı söz konusudur. Diğer taraftan Rusya'da karbondioksit emisyonundan dışa açıklığa doğru \%1 anlamlılık düzeyinde bir nedensel bağıntı bulunmaktadır.

Tablo 6. Panel Nedensellik Sonuçları $\left(\mathrm{CO}_{2}, \mathrm{Y}^{2}\right)$

\begin{tabular}{|c|c|c|c|c|c|c|c|c|}
\hline \multirow{3}{*}{ Ülkeler } & \multicolumn{4}{|c|}{$\mathrm{H}_{0}: \operatorname{lnCO} \mathrm{C}_{2}$ nedeni değildir $\ln \mathrm{Y}^{2}{ }^{2}$ nin } & \multicolumn{4}{|c|}{$\mathrm{H}_{0}: \ln \mathrm{Y}^{2}$ nedeni değildir $\ln \mathrm{CO}_{2}$ 'nin } \\
\hline & \multirow[b]{2}{*}{$\begin{array}{l}\text { Wald } \\
\text { Testi }\end{array}$} & \multicolumn{3}{|c|}{ Bootstrap Kritik Değerleri } & \multicolumn{4}{|c|}{ Bootstrap Kritik Değerleri } \\
\hline & & $\% 1$ & $\% 5$ & $\% 10$ & $\begin{array}{l}\text { Wald } \\
\text { Testi }\end{array}$ & $\% 1$ & $\% 5$ & $\% 10$ \\
\hline Brezilya & $14.573 * * *$ & 5.066 & 3.241 & 2.308 & 13.842 & 33.983 & 25.620 & 22.891 \\
\hline Rusya & $31.798 * * *$ & 2.974 & 1.725 & 1.136 & $10.483 * *$ & 12.877 & 10.328 & 8.820 \\
\hline Hindistan & 0.001 & 14.589 & 8.533 & 6.513 & 20.067 & 39.155 & 27.235 & 23.742 \\
\hline Çin & $7.929 *$ & 13.598 & 9.004 & 6.004 & 0.371 & 15.761 & 12.353 & 11.022 \\
\hline Türkiye & 0.658 & 66.115 & 49.514 & 40.870 & 4.425 & 83.181 & 56.181 & 44.365 \\
\hline
\end{tabular}

Not: Maksimum gecikme uzunluğu 3 olarak belirlenmiş ve Akaike bilgi kriteri tercih edilmiştir. Kritik değerler 1000 Bootstrap'a dayanmaktadır. *** istatistiki olarak \%1 anlamlılık düzeyini göstermektedir.

Gelirin karesi ile karbondioksit emisyonu arasındaki nedensellik ilişkilerini gösteren bulgulara göre; sadece Rusya'da, çift yönlü bir nedensellik bağıntısı söz konusudur. Diğer taraftan Brezilya'da \%1 anlamlılık düzeyinde, Çin'de ise \%10 anlamlılık düzeyinde karbondioksit emisyonundan gelirin karesine doğru tek yönlü bir nedensellik bulunmaktadır. Gelirin karesi ile karbondioksit emisyonu arasındaki nedensel bağıntı sonuçları; gelir ve karbondioksit emisyonu arasındaki nedensel bağıntı sonuçları ile aynıdır.

MG, AMG ve CCE tahmincilerine göre hesaplanmış olan uzun ve kısa dönem katsayıları Tablo 7'de yer almaktadır. Heterojenliği dikkate alarak kısa ve uzun dönem ilişkilerini gösteren dinamik MG tahmincisine göre; uzun dönemde Çin'de kısa dönemde ise Türkiye'de ÇKE hipotezinin geçerli olduğu sonucuna ulaşılmıştır. Diğer taraftan yatay kesit bağımlılığı ile heterojenliği birlikte dikkate alan AMG tahmincisi ise Rusya, Çin ve Türkiye'de ÇKE hipotezinin geçerliliğini doğrulamaktadır. Son olarak CCE tahmincisine göre de ÇKE hipotezinin sadece Türkiye'de geçerli olduğu bulgusu elde edilmiştir. Ayrıca uzun dönemde, elektrik tüketiminin karbondioksit emisyonu üzerindeki etkisine dair istatistiki olarak anlamlı sonuçlar tüm tahmincilere göre pozitiftir. Dışa açıklık ise MG ve AMG tahmincilerine göre Çin'de karbondioksit emisyonunu azaltırken; CCE tahmincisi Brezilya'da dışa açıklı̆ı̆ karbondioksit emisyonunu artırdığını göstermiştir. 
MG test sonuçlarına göre gelir değiş̧enine ait ÇKE dönüşüm noktası Çin için 2.083 dolar iken, AMG test sonuçlarına göre 1.750 dolar olarak hesaplanmıştır. CCE test sonuçlarına göre gelir değişkenine ait ÇKE dönüşüm noktası Türkiye için 4.033 dolar iken, AMG test sonuçlarına göre 4.750 dolar olarak hesaplanmıştır. Rusya'da ise gelir değişkenine ait ÇKE dönüşüm noktası AMG test sonuçlarına göre 3.800 dolar düzeyindedir. 
Tablo 7. Katsayı Tahminleri, Yatay Kesit bağımlılık ve Homojenlik Test sonuçları

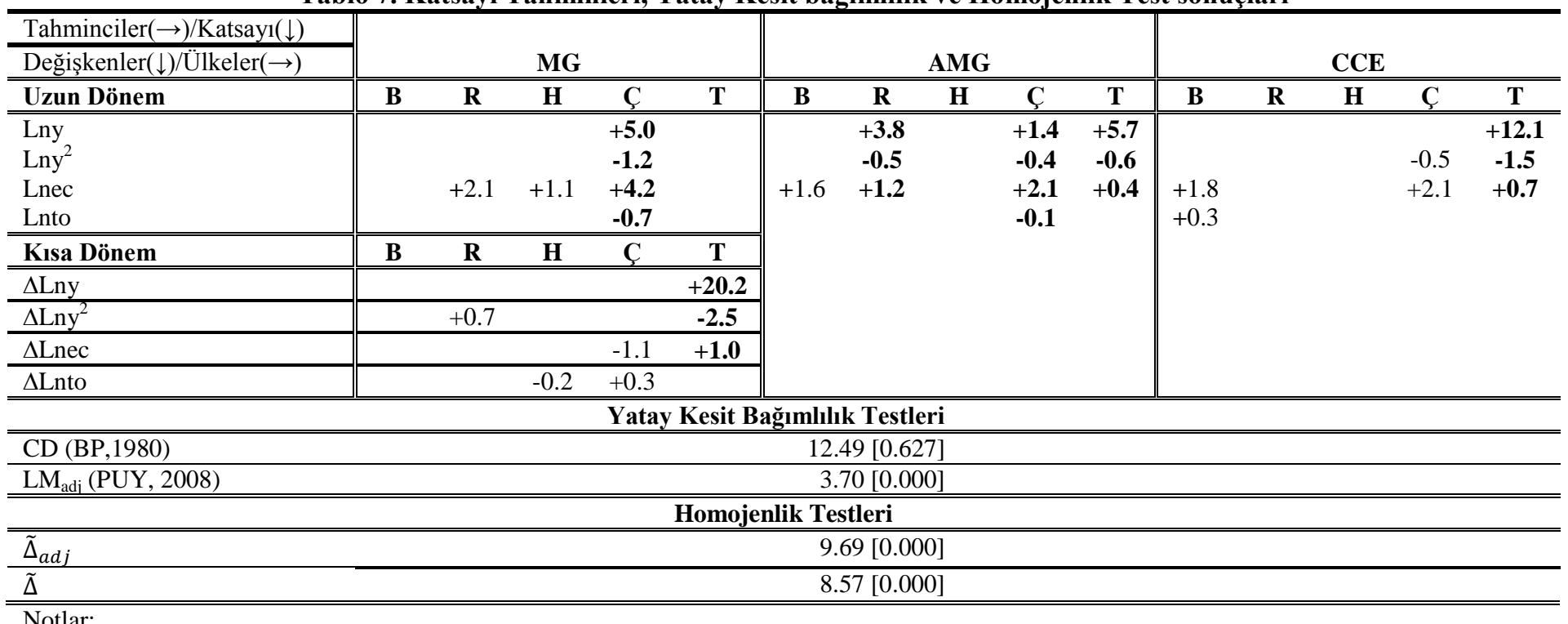

MG: Ortalama Grup Tahmincisi, AMG: Genişletilmis Ortalama Grup Tahmincisi, CCE: Ortak İliškili Etkiler Tahmincisi

B: Brezilya, R: Rusya, H: Hindistan, Ç: Çin, T: Türkiye

$\mathrm{LM}_{\text {adj }}$ (Puy, 2008): Pearan $v d$. (2008) tarafından geliştirilen sapması düzeltilmiş LM testi (yatay kesit bağımlılık testi),

$\tilde{\Delta}_{a d j}$ ve $\tilde{\Delta}$ : Pesaran ve Yagamata (2008) tarafindan geliştirilen homojenlik veya Delta testini ((Slope homogeneity) ya da $\tilde{\Delta}$ testi),

+: Tahmin edilen katsayının işaretinin pozitif olduğunu,

- : Tahmin edilen katsayının işaretinin negatif olduğunu,

[ ]: Test olasıllk değerini göstermektedir.

Tabloda yer verilen sonuçlar gerçekleștirilen testlerden elde edilen sonuçlardan istatistiki olarak anlamlı çıanları (pozitif (+) ve negatif (-))

kapsamaktadır 


\section{SONUC}

Ülkelerin ekonomik ve sosyal kalkınması bakımından üretim artı̧̧ önemli bir fonksiyon üstlenmektedir. Üretimi artırmak amacıyla daha fazla üretim faktörü kullanılması ise bir taraftan gelir artışına neden olurken; diğer taraftan da ekolojik sorunlara yol açabilmektedir. Çevresel Kuznets Eğrisi Hipotezi kalkınmanın başlangıç aşamalarında kişi başına düşen gelir artarken kirliliğin de arttığını, ancak belli bir gelir düzeyinden sonra çevresel düzenlemelerin iyileşmesi ve temiz teknolojilerin ağırlık kazanmasına bağlı olarak söz konusu sorunun düzelmeye başladığını ifade etmektedir. $\mathrm{Bu}$ çalışmada ekonomik büyüme, dışa açıklık ve elektrik tüketimi ile $\mathrm{CO}_{2}$ emisyonu arasındaki ilişkiler 1992-2014 dönemini kapsayan yıllık verilerden hareketle BRIC-T Ülkeleri için panel veri analizi kullanılarak test edilmiştir.

Nedensellik bulgularına göre; Rusya'da gelir ve karbondioksit emisyonu arasında çift yönlü bir nedensellik söz konusudur. Literatürde, gelir ve karbondioksit emisyonu arasındaki çift yönlü nedensellik ilişkisine dair Halıcıoğlu (2009) Türkiye, Apergis ve Payne (2009) Orta Amerika ülkeleri, Ching (2010) Çin, Kohler (2013) Güney Afrika, Omri (2013) MENA ülkeleri ve Shahbaz vd. (2013) Endonezya için benzer sonuçlar elde etmişlerdir. Gelir ve karbondioksit emisyonu arasındaki çift yönlü nedensellik ilişkisinin tespit edildiği ülkelerin büyük bir kısmı yükselen ülke ekonomileri olarak dikkat çekmektedir. Bu anlamda, Rusya için elde edilen çift yönlü nedensellik ilişkisi yukarıda sıraladığımız çalışmaların sonuçlarını teyit etmektedir. Diğer yandan Hindistan'da elektrik tüketiminden ve Brezilya'da ise dışa açıklıktan karbondioksit emisyonuna doğru bir bağıntı tespit edilmiştir.

MG testi uzun dönemde ÇKE hipotezinin Çin'de, kısa dönemde ise hipotezin Türkiye'de geçerli olduğunu göstermiştir. Aynı zamanda dışa açıklığın Çin'de karbondioksit emisyonunu azaltıcı yönde bir etki meydana getirdiği; elektrik tüketimindeki artışın ise emisyon düzeyi üzerinde pozitif yönde bir sonuç yarattığı görülmüştür. Diğer taraftan Türkiye'de de Çin'de olduğu gibi elektrik tüketimi ile karbondioksit emisyonu arasında aynı yönlü bir ilişsi olduğu tespit edilmiştir. Çin'e ilişkin MG testi uzun dönem bulguları ile AMG testi bulguları örtüşmekte iken; Türkiye'de ise MG kısa dönem bulguları ile CCE ve AMG testi bulguları benzerlik göstermektedir. Son olarak AMG test sonuçlarına göre Rusya için ÇKE hipotezi geçerlilik taşımakta ve elektrik tüketimindeki artış karbondioksit emisyonunu yükseltmektedir.

Elde edilen bulgulara göre; ekonomik büyüme, çevre üzerinde doğrudan veya dolaylı olarak etkiler meydana getirmektedir. Kalkınmanın ilk aşamalarında genel olarak bu etkinin, olumsuz yönde gerçekleştiği kabul edilir. Üretim artışının doğal kaynaklara geri getirilemez boyutlarda zarar vermemesi, dolayısıyla sürdürülebilir bir 
büyüme ikliminin oluşturulabilmesi için; fosil yakıt tüketiminin sınırlandırılarak yenilenebilir enerji üretiminin artırılmasında, ağaçlandırma çalışmalarında kamu-özel kesim işbirliğinin güçlendirilmesinde, özellikle su tüketiminde tasarruf bilincinin yaygınlaştırılmasında, üretimde yüksek verimliliği sağlayabilecek ileri teknolojilerin daha fazla kullanılmasında ve endüstriyel üretim süreçlerinde kirlilik önleme maliyetlerini düşürecek ar-ge çalışmalarının desteklenmesinde fayda bulunmaktadır.

\section{NOTLAR:}

${ }^{1}$ Grossman ve Krueger (1994) tarafından oluşturulmuştur. Detaylı bilgi için bkz. Grossman ve Krueger (1994: 9-10).

${ }^{2}$ Panayotou (1997) tarafindan oluşturulmuştur. Detaylı bilgi için bkz. Panayotou (1997: 475-477).

${ }^{3}$ Stern (2004b) tarafindan oluşturulmuştur. Detaylı bilgi için bkz. Stren (2004b: 519-521).

\section{KAYNAKÇA}

Acaravc1, A., C. Bozkurt, S. Erdoğan (2015), "MENA Ülkelerinde Demokrasi-Ekonomik Büyüme İlişkisi”, İşletme ve İktisat Çalışmaları Dergisi, 3(4), 2015, 119-129.

Altıntaş, H., M. Mercan (2015), “Ar-Ge Harcamaları ve Ekonomik Büyüme İlişkisi: OECD Ülkeleri Üzerine Yatay Kesit Bağımlılığı Altında Panel Eşbütünleşme Analizi”, Ankara Üniversitesi, S.B.F Dergisi, 70(2), 345-376.

Ang, J.B. (2008), "Economic development, pollutant emissions and energy consumption in Malaysia", Journal of Policy Modeling, 30, 271-278.

Apergis, N., J.E. Payne (2009), " $\mathrm{CO}_{2}$ emissions, energy usage, and output in Central America", Energy Policy, 37, 3282-3286.

Apergis, N., İ. Öztürk (2015), "Testing Environmental Kuznets Curve Hypothesis in Asian Countries”, Ecological Indicators, (52), 16-22.

Arı, A., F. Zeren (2011), “ $\mathrm{CO}_{2}$ Emisyonu ve Ekonomik Büyüme: Panel Veri Analizi”, Yönetim ve Ekonomi, 18(2), 37-47.

Atasoy, B.S. (2017), "Testing the Environmental Kuznets Curve Hypothesis Across the U.S.: Evidence From Panel Mean Group Estimators", Renewable and Sustainable Energy Reviews, 77, 731-747.

Aytun, C. (2014), “Çevresel Kuznets Eğrisi Hipotezi: Panel Veri Analizi”, Akademik Bakış Dergisi, 44.

Blackburne, III. E.F., M.W. Frank (2007), "Estimation of nonstationary heterogeneous panels", The Stata Journal, 7(2), 197-208.

Breusch T.S., A.R. Pagan (1980), “The Lagrange Multiplier Test and its Applications to Model Specification in Econometrics", Review of Economic Studies, 47(1), 239-253.

Carson, R.T. (2010), “The Environmental Kuznets Curve: Seeking Empirical Regularity and Theoretical Structure", Review of Environmental Economics and Policy 4(1), 3-23. 
Cebeci, A., E. Torres, H.G. Beken (2018), Current Debates in Economics, London: IJOPEC Publication.

Ching-Chih, C. (2010), "A multivariate causality test of carbon dioxide emissions, energy consumption and economic growth in China", Applied Energy, 87, 3533-3537.

Dasgupta, S., B. Laplante, H. Wang, D. Wheeler, (2002), "Confronting the Environmental Kuznets Curve", The Journal of Economic Perspectives, 16(1), 147-168.

Delice, G., M. Mercan, S. Sezer (2012), Dış Borç Stokunun İhracat Performansı Üzerindeki Etkisine AB Ülkeleri ve Türkiye Perspektifinden Bir Bakış, http://teacongress.org/papers2012/DELICE-MERCANSEZER.pdf, E.T.:04.02.2018.

Dinda, S. (2004), "Environmental Kuznets Curve Hypothesis: A Survey”, Ecological Economics, 49, 431-455.

Eberhardt, M., S. Bond (2009), Cross-section dependence in nonstationary panel models: A novel estimator, MPRA Paper No. 17692, University Library of Munich.

Eberhardt, M., F. Teal (2010), Productivity Analysis in Global Manufacturing Production, Discussion Paper 515, Department of Economics, University of Oxford.

Eberhardt, M., F. Teal (2011), "Econometrics for Grumblers: A new look at the Literature on Crosscountry Growth Empirics", Journal of Economic Surveys, 25, 109-155.

Eberhardt, M. (2012), "Estimating Panel Time-Series Models with Heterogeneous Slopes, The Stata Journal, 12(1), 61-71.

Ehrlich, P. (1968), The Population Bomb, New York: Ballentine.

Erol, E.D., F. Erataş, H.B. (2013), “Çevresel Kuznets Eğrisi'nin Yükselen Piyasa Ekonomilerindeki Geçerliliği: Panel Veri Analizi”, Akademik Sosyal Araştırmalar Dergisi, 1(1), 400-415.

Ertugrul H.M., M. Cetin, F. Seker, E. Doğan (2016), “The Impact of Trade Openness on Global Carbon Dioxide Emissions: Evidence From The Top Ten Emitters Among Developing Countries", Ecological Indicators, 67, 543-555.

Farhani, S., S. Mrizak, A. Chaibi, C. Rault (2014), “The Environmental Kuznets Curve and Sustainability: A Panel Data Analysis”, Energy Policy, 71, 189-198.

Gashi, J., E. Guma (2017), The Environmental Kuznets Curve (EKC): An Analysis for the Balkans, 13th International Conference of ASECU, Durres, www.asecu.gr/files/13th_conf_files/13th-conf-asecu-proceedings.pdf, E.T.:01.02.2018.

Gönel, F.D. (2010), Kalkınma Ekonomisi, Ankara: Efil Yayınevi.

Grossman, G.M., A.B. Krueger (1991), Environmental Impacts of a North American Free Trade Aggrement, NBER Working Paper No. 3914, National Bureau of Economic Research, Cambridge.

Grossman, G.M., A.B. Krueger (1994), Economic Growth and the Environment, NBER Working Paper No. 4634, National Bureau of Economic Research, Cambridge.

Grossman, G.M., A.B. Krueger (1995), "Economic Growth and the Environment", The Quarterly Journal of Economics, 110(2), 353-377.

Haq, I.U., S. Zhu, M. Shafiq (2016), "Empirical Investigation of Environmental Kuznets Curve for Carbon Emission in Morocco", Ecological Indicators, 67, 491-496. 
ÖZMEN, GERÇEKER, MUCUK | Economic Growth, Trade Openness, Electricity Consumption...

Halıcıoğlu, F. (2009), “An Econometric study of $\mathrm{CO}_{2}$ Emissions, Energy Consumption, Income and Foreign Trade in Turkey", Energy Policy, 37, 1156-1164.

Halkos, G.E. (2003), "Environmental Kuznets Curve for Sulfur: Evidence Using GMM Estimation and Random Coefficient Panel Data Models", Environment and Development Economics, 8(4), 581-601.

Hanif, I., P. Gago-de-Santos (2017), “The Importance of Population Control and Macroeconomic Stability to Reducing Environmental Degradation: An Empirical Test of the Environmental Kuznets Curve for Developing Countries”, Environmental Development, 23, 1-9.

Holtz-Eakin, D., T.M. Selden (1992), Stoking The Fires? $\mathrm{CO}_{2}$ Emissions and Economic Growth, NBER Working Paper No. 4248, National Bureau of Economic Research, Cambridge.

Kanjilal, K., S. Ghosh (2013), "Environmental Kuznet's Curve for India: Evidence From Tests For Cointegration With Unknown Structural Breaks”, Energy Policy, 56, 509-515.

Kar, M., Ş. Nazlıŏglu, H. Ağır (2011), "Financial Development and Economic Growth Nexus in the MENA Countries: Bootsrap Panel Granger Causality Analysis", Economic Modelling, 28, 685-693.

Kılıc, N.O., B. Açdoyuran, H.S. Calhan (2017), "Information Communication Technologies Export and Economic Growth Relationship: An Analysis on Selected Countries", Journal of Business, Economics and Finance (JBEF), 6(4), 328-335.

Koçbulut, Ö, H. Altıntaş (2016), "İkiz Açıklar ve Feldstein-Horioka Hipotezi: OECD Ülkeleri Üzerine Yatay Kesit Bağımlılığı Altında Yapısal Kırılmalı Panel Eşbütünleşme Analizi”, Erciyes Üniversitesi İktisadi ve İdari Bilimler Fakültesi Dergisi, 48, 145-174.

Kohler, M. (2013), $\mathrm{CO}_{2}$ Emissions, Energy Consumption, Income and Foreign Trade: A South African Perspective, ERSA Working Paper 356, July.

Kónya, L. (2006), "Exports and growth: Granger Causality Analysis on OECD Countries with a Panel Data Approach", Economic Modelling, 23, 978-92.

Kuznets, S. (1955), "Economic Growth and Income Inequality”, American Economic Review, 45, $1-28$.

Lapinskienè, G., M. Tvaronavičienè, P. Vaitkus (2013), "Analysis of the Validity of Environmental Kuznets Curve for the Baltic States", Environmental and Climate Technologies, 12, 41-46.

Lora, J.C.T, B.C. Bermúdez, C.A.C. Vizcaíno, W.J.I. Pinedo (2013), "The Environmental Kuznets Curve (EKC): An Analysis Landfilled Solid Waste in Colombia”, Revista Facultad de Ciencias Económicas: Investigación y Reflexión, 21(2), 7-16.

Meadows, D.H., D.L. Meadows, J. Randers, W.W. Behrens (1972), The Limits to Growth. New York: Universe Books.

Nasir, M., F.U. Rehman (2011), "Environmental Kuznets Curve for Carbon Emissions in Pakistan: An Empirical Investigation”, Energy Policy, 39, 1857-1864.

Nazlığlu, Ş. (2010), Makro İktisat Politikalarının Tarım Sektörü Üzerindeki Etkileri: Gelişmiş ve Gelişmekte Olan Ülkeler için Bir Karşılaştırması, Erciyes Üniversitesi Sosyal Bilimler Enstitüsü, Yayımlanmamış Doktora Tezi, Kayseri. 
Nazlıoğlu, S., F. Lebe, S. Kayhan (2011), "Nuclear Energy Consumption and Economic Growth in OECD Countries: Cross-Sectionally Dependent Heterogeneous Panel Causality Analysis", Energy Policy, 39, 6615-6621.

Nugent, J.B. (1983), "An Alternative Source of Measurement Error as an Explanation for the Inverted-U Hypothesis", Economic Development and Cultural Change, 31(2), 385-396.

Omri, A. (2013), $\mathrm{CO}_{2}$ Emissions, Energy Consumption and Economic Growth Nexus in MENA countries: Evidence from Simultaneous Equations Models, Munich Personal RePEc Arcive, MPRA Paper No. 82501. April.

Özkan, G., E. Karakaş, (2018), “ÇKE'nin 25 OECD Ülkesinde Panel Veri Analizi ile Test Edilmesi: 1990-2014 Yıllar1", International Journal of Academic Value Studies (Javstudies), 4(20), 631-641.

Özşahin, Ş. (2017), “An Examination of Bilateral J-curve: Evidence from Turkey and her 20 Major Trading Partner", Theoretical and Applied Economics, 2(611), 221-236.

Özşahin, Ş., M. Gömleksiz (2016), "Ekonomik Gelişmişlik ve Ar-Ge Harcamaları: Yükselen Piyasa Ekonomileri Üzerine Panel Eşbütünleşme ve Nedensellik Analizi”, Uluslararası Yönetim, Ekonomi ve Politika Kongresi, 4, 3702-3717.

Panayotou, T. (1993), Empirical Tests and Policy Analysis of Environmental Degradation at Different Stages of Economic Development, World Employment Programme Research, Working Paper, International Labour Organization, Geneva.

Panayotou, T. (1997), "Demystifying the Environmental Kuznets Curve: Turning a Black Box into a Policy Tool", Environment and Development Economics, 2, 465-484.

Panayotou, T. (2003), "Economic Growth and the Environment", in Secretariat of the Economic Comission for Europe Geneva (ed.), Economic Survey of Europe, Geneva: United Nations, 45-72.

Pata, U.K., H. Terzi (2017), “The Relationship between Renewable and Nonrenewable Energy Consumption and Economic growth in G7 Countries: Evidence from Bootstrap Panel Causality Test”, Economica, 13(5), 243-252.

Pesaran, M.H., R. Smith (1995), "Estimating Long-Run Relationships from Dynamic Heterogeneous Panels", Journal of Econometrics, 68, 79-113.

Pesaran, H.M. (2004), General Diagnostic Test for Cross Section Dependence in Panels, IZA Discussion Paper 1240, Institute for the Study of Labor.

Pesaran, M.H. (2006), "Estimation and Inference in Large Heterogeneous Panels with a Multifactor Error Structure", Econometrica, 74(4), 967-1012.

Pesaran H.M., A. Ullah, T. Yamagata (2008), “A bias-adjusted LM test of error cross-section independence”, Econometrics Journal, 11, 105-127.

Pesaran H.M., T. Yamagata (2008), "Testing Slope Homogeneity in Large Panels", Journal of Econometrics, 142, 50-93.

Piketty, T. (2013), Yirmi Birinci Yüzyılda Kapital, İstanbul: Türkiye İş Bankası Kültür Yayınları.

Podkorytova, O., Y. Raskina (2014), Trade and the Environmental Kuznets Curve: A Panel Data Approach, CEEES Paper Series CE3S-04/14, European University at St. Petersburg, Department of Economics. 
ÖZMEN, GERÇEKER, MUCUK | Economic Growth, Trade Openness, Electricity Consumption...

Polat, M., A. Uslu (2017), İşletmelerin Finansal Performanslarının Hisse Senedi Fiyatı Üzerindeki Etkisi, Uluslararası Ekonomi, Siyaset ve Yönetim Sempozyumu, Ankara: Ekin Yayınevi.

Rostow, W.W. (1966), İktisadi Gelişmenin Merhaleleri 'Komünist Olmayan Bir Manifesto', İstanbul: Milli Eğitim Basımevi.

Saboori, B., J.B. Sulaiman, S. Mohd (2012), “An Empirical Analysis of the Environmental Kuznets Curve For CO2 Emissions in Indonesia: The Role of Energy Consumption and Foreign Trade", International Journal of Economics and Finance, 4(2), 243-251.

Sambodo, M.T., E. Lestari (2012), "Environmental Kuznets Curve: Panel Data Evidence from Developing Countries", Economics and Finance in Indonesia, 60, 175-196.

Selden, T.M., D. Song (1994), "Environmental Quality and Development: Is There a Kuznets Curve for Air Pollution Emissions?", Journal of Environmental Economics and Management, 27(2), 147-162.

Shafik, N., S. Bandyopadhyay (1992), Economic Growth and Enviromental Quality Time-Series and Cross-Country Evidence, World Bank Policy Research Working Paper WPS 904.

Shahbaz, M., H.H. Lean, M.S. Shabbir (2012), "Environmental Kuznets Curve hypothesis in Pakistan: Cointegration and Granger causality", Renewable and Sustainable Energy Reviews, 16, 2947-2953.

Shahbaz, M., N. Khraief, G.S. Uddin, I. Ozturk (2014), "Environmental Kuznets curve in an open economy: A bounds testing and causality analysis for Tunisia", Renewable and Sustainable Energy Reviews, 34, 325-336

Shahbaz, M., Q.M.A. Hyei, A.K. Tivari, N.C. Leitão (2013), "Economic growth, energy consumption, financial development, international trade and $\mathrm{CO}_{2}$ emissions in Indonesia”, Renewable and Sustainable Energy Reviews, 25, 109-121.

Shahbaz, M., S.J.H. Shahzad, M.K. Mahalik, P. Sadorsky (2017), How Strong is the Causal Relationship between Globalization and Energy Consumption in Developed Economies? A Country-Spesific Time-Series and Panel Analysis, MPRA Paper No. 80718, Munich.

Sommerova, L. (2018), Environmental Kuznetz Curve - The Studies for the Czech Republic and Finland, Masaryk University Faculty of Economics and Administration, Master Thesis.

Songur, Y.D. (2017), "Doğrudan Yabancı Yatırımlar ve Dış Ticaret'in Gayri Safi Yurtiçi Hasıla Üzerine Etkisi: Avrasya Ülkeleri Örneği”, Bulletin of Economic Theory and Analysis, 2(2), 117-133.

Stern, D.I. (2004a), "The Rise and Fall of the Environmental Kuznets Curve", World Development, 32(8), 1419-1439.

Stern, D.I. (2004b), “Environmental Kuznets Curve”, Encyclopedia of Energy, 2, 517-525.

Topallı, N. (2017), "Ekonomik Büyüme, İhracat ve $\mathrm{C}_{2}$ Arasındaki Eşbütünleşme İlişkisi: BRICS ve Türkiye Örneği”, Avrasya Sosyal ve Ekonomi Araştırmaları Dergisi, 4(12), 685-698.

Topaloğlu, E.E. (2017), "Bankalarda Finansal Kırılganlığı Etkileyen Faktörleri Panel Veri Analizi ile Belirlenmesi”, Eskişehir Osmangazi Üniversitesi İ̈BF Dergisi, 13(1), 15-38. 
Bric-T Ülkelerinde Ekonomik Büyüme, Dışa Açıklık, Elektrik Tüketimi | ÖZMEN, GERÇEKER, MUCUK

Torras, M., J.K. Boyce (1998), "Income, Inequality, and Pollution: A Reassessment of the Environmental Kuznets Curve", Ecological Economics, 25, 147-160.

United Nations (1987), Our common future: report of the world commission on environment and development. Switzerland: WCED.

Zaman, K., M.A. Moemen (2017), "Energy Consumption, Carbon Dioxide Emissions and Economic Development: Evaluating Alternative and Plausible Environmental Hypotesis for Sustainable Growth", Renewable and Sustainable Energy Reviews, 74, 1119-1130. 